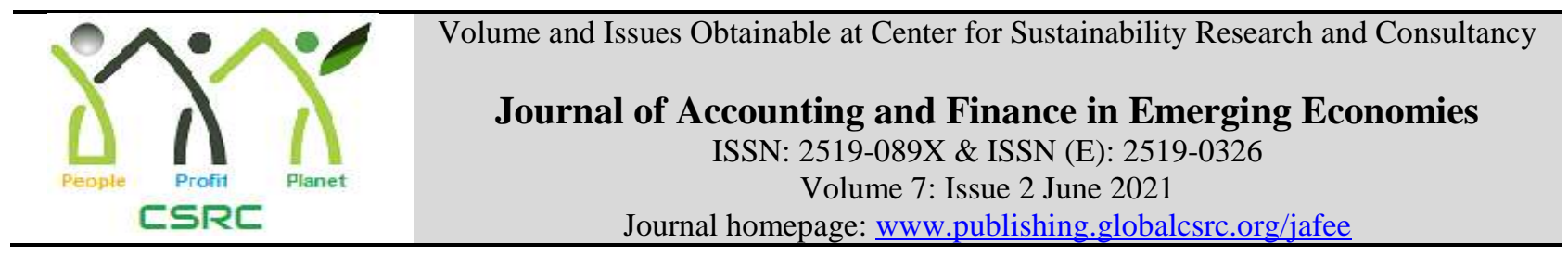

\title{
Measurement and Determinants of Financial Performance of Modaraba Companies: A Case Study of Pakistan
}

Qaisar Maqbool Khan, Department of Commerce, Bahauddin Zakariya University, Multan, Pakistan

*Rehana Kouser, Department of Commerce, Bahauddin Zakariya University, Multan, Pakistan

*Corresponding author's email: rehanakousar@bzu.edu.pk

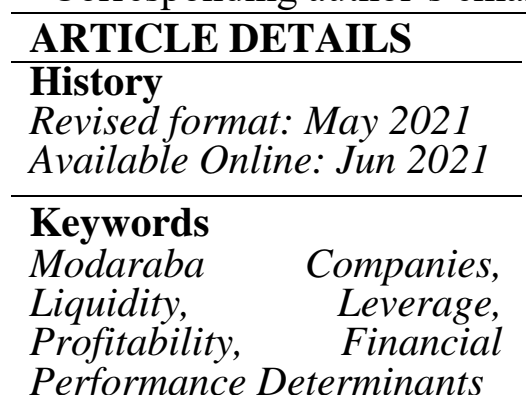

Performance Determinants

JEL Classification

M40, M41

\begin{abstract}
Purpose: Profitability measurement is a comparative statistic that describes the relationships between overall profit and other financial determinants of the firm.

Design/Methodology/Approach: The focus of this study is to measure the technical (TE), pure technical (PTE) and scale efficiency (SE) scores via Data Envelopment Analysis (DEA) of modaraba companies operating in Pakistan. The next stage is to study the empirical relationship between profitability, liquidity, leverage, and macroeconomic performance drivers. Financial statement data for 2010 to 2019 have been analyzed.
\end{abstract}

Findings: Empirical findings of descriptive statistics, correlation and regression were measured. These empirical results reveal that capital ratio (CR) and operating expenses to net income (OENI) had negative correlation with PTE, SE and TE. Whereas the age of the firm had a negative correlation with PTE and TE and positive correlation with $\mathrm{SE}$, moreover, exchange rate (EXC) PKR to USD, log of total assets (LTA) and management expenses (ME) had negative correlation with SE and positive correlation with PTE and TE. Furthermore, inflation (INF) had negative correlation with PTE and positive correlation with SE and TE. Moreover, number of certificates (NOC) had negative correlation with SE and TE and positive correlation with PTE.

Implications/Originality/Value: Findings will be helpful to the management and policy makers for enhancing future financial performance by concentrating on these economic factors. More detailed and extensive data from the financial and non-financial aspects is suggested to support the hypothesized relationship of efficiency measures and determinants.

(C) 2021 The authors, under a Creative Commons AttributionNonCommercial 4.0 Recommended citation: Khan, Q. M. and Kouser, R. (2021). Measurement and Determinants of Financial Performance of Modaraba Companies: A Case Study of Pakistan. Journal of Business and Social Review in Emerging Economies, 7 (2), 443-465 


\section{Introduction}

All over the world financial sector plays integral part of a sustainable economy. It also plays vital role in under developing country like Pakistan. In Pakistan it contributes around 5\% of total GDP. So, it is necessary to maintain a strict, stable, and robust financial system for the country's economic well-being. As per State Bank of Pakistan (SBP), yearly financial data analysis reports Pakistani financial sector is a blend and integration of several institutions including public sector banks, private sector banks, specialized banks, foreign banks, development finance institutions (DFIs), micro finance banks, leasing companies, investment banks, mutual fund companies, modarba companies, exchange companies, life insurance corporations, non-life insurance corporations, takaful companies, housing finance companies and venture capital. Among these all Modaraba companies have special importance for a developing economy.

So, first we discuss: what exactly is Modaraba? "Modaraba refers to a firm in which some people invest their money and managers or Modaraba contribute their managerial skills. As per agreedupon percentage/ratio the profit is divided between the two parties. In the event of a loss, it is dispersed among financiers in proportion to their invested capital."

\section{Major Features of Modaraba Companies}

- It is a contract in which one party offers management expertise and the other party offers capital funding to run the firm.

- Profit is distributed in accordance with the agreed-upon ratio.

- It might be "Multiple Purpose" or "Special Purpose."

- The "Modaraba Companies Modaraba Rules,1981" must apply to this firm.

- Under Modaraba guidelines, the entity providing management expertise must own at least $10 \%$ of the company.

- Company can float a Modaraba after getting registered status for Modaraba floatation.

- A certificate from the Religious Board stating that the enterprise does not violate Islamic law is also sought.

- Each Modaraba firm must select a chartered accountant as auditor, who will confirm finances and objectives.

The optimal balance between liquidity and profitability has become an unavoidable reality that needs pragmatic managerial attention in practically every firm. Profitability and liquidity are two distinct but interrelated arguments that need management's attention depending on the form of the economic unit. It is preferable to have a corrective and optimal level of liquidity because it is inversely related to profitability. Although liquidity increases protect against default risk, trussing important cash in unproductive segments immediately harms profitability. Maintaining low level of liquidity is ensuring that extra cash to be invested in profitable ventures. This also leads to failure since the metaphor "short term survival is vital for long run" is widely accepted in financial literature. According to Saluja and Kumar (2012 the management of current assets and current liabilities in such a way that profitability is optimal, as a firm seeks to preserve a high level of current assets and potential minimum current liabilities to maintain solvency, has become a major problem. This proposition has a negative influence on the organization's profitability.

The failure of Modaraba (profit and loss sharing contracts to be implemented is related to a major agency problem that leads to moral hazards and adverse selection (Khan, 1985; Haque and Mirakhor, 1986; Bashir, 1996; Bashir, 2001; Al-Jarhi. Because Islamic partnership contracts incorporate both a principal and an agent, a conflict of interest may exist between both parties. In some circumstances, the agent may have other interests and increasing the firm's worth is not their top goal; in these circumstances, the entrepreneur may not devote their full attention to the 
project (Samadzadeh \& Melande, 2012.

Sarker (2000) claimed that the main cause of asymmetric information in Modaraba contracts is the entrepreneur's self-interest which causes inaccurately reporting the project's outcome. Later, it was observed that entrepreneurs with lower-than-average profits prefer stock contracts to debt contracts to minimize loss in the event of failure. (Iqbal \& Lewis, 2009; Sapuana, 2016. Because of insufficient information about the entrepreneur, their background, and their talents, only $20 \%$ of projects in Islamic banks globally are financed via PLS contracts (Jouaber\& Mehri, 2012.

\section{Research Gap Analysis}

Only few studies are conducted in Pakistan on modaraba firm performance measurement and firm specific and macroeconomic determinants of its performance. Further to analyze their significant impact on technical, pure technical and scale efficiency scores. Therefore, the following study will be helpful for future studies and researchers to get useful information regarding the measurement and determinants of financial performance in the Modaraba companies of Pakistan. Nevertheless, this study takes various determinants related to profitability, liquidity, leverage and macroeconomic measures as well and other economic factors.

\section{Objectives of the study}

- To measure the efficiency scores (technical, pure technical and scale of Modaraba Companies of Pakistan, during last ten years financial period of 2010 to 2019via Data Envelopment Analysis (DEA).

- To measure and analyze the impact of profitability, liquidity, leverage and macroeconomic determinants on efficiency scores of Modaraba companies of Pakistan.

\section{Research Questions of the study}

1. Does age of the firm impact on TE, PTE \& SE?

2. Does log of total assets of the firm impact on TE, PTE \& SE?

3. Does number of certificates of the firm impact on TE, PTE \& SE?

4. Does return on equity of the firm impact on TE, PTE \& SE?

5. Does return on capital employed of the firm impact on TE, PTE \& SE?

6. Does return on asset of the firm impact on TE, PTE \& SE?

7. Does return on revenue of the firm impact on TE, PTE \& SE?

8. Does operating expense to net income of the firm impact on TE, PTE \& SE?

9. Does management expense of the firm impact on TE, PTE \& SE?

10. Does earning per certificate of the firm impact on TE, PTE \& SE?

11. Does current ratio of the firm have a significant impact on TE, PTE \& SE?

12. Does total liabilities to total asset of the firm impact on TE, PTE \& SE?

13. Does capital ratio of the firm impact on TE, PTE \& SE?

14. Does breakup value per certificate of the firm impact on TE, PTE \& SE?

15. Does gross domestic product of Pakistan impact on TE, PTE \& SE?

16. Does rate of inflation of Pakistan impact on TE, PTE \& SE?

17. Does rate of interest of Pakistan impact on TE, PTE \& SE?

18. Does exchange rate of Pakistan impact on TE, PTE \& SE?

\section{Literature Review}

In the literature review of finance and economics, the term the capacity to "liquidate" is referred to as "liquidity." to exchange economic assets for cash without diminishing fair value. Liquidity is a flow concept, and the capacity to identify such flows is essential, failure results in illiquid operations, which damages profitability. Monetary policy is affected by financial institutions' liquidity policies. (Nikolaou et al, 2009. 
The prospect of such a loss creates the default risk horizon for financial institutions, lowering their earning potential. Future fund inflows and outflows, as well as future price realization, are the two fundamental components of funding liquidity. In a money market governed by increasing financing availability, financial institutions are more likely to realize higher prices (Drehmann \& Nikolaou, 2012).

Chamberlain (2009)The importance of profitability and efficiency variables in influencing significant enterprises' investment behavior was investigated utilizing a long-term survival model akin to profitability interpretation as the investment foundation. The paper examines the underlying link using both historical and replacement cost data, indicating that the long-term survival model to patronize investment behavior displays the same compatibility as other techniques, although liquidity flows in the model appear to be the most effective metric.

Every business seeks to maintain appropriate profitability and liquidity since liquidity has a significant impact on the firm's earnings per share (EPS), portion which is distributed to shareholders. Because one rises, the other falls, liquidity and profitability are inextricably related. (Saleem \& Rehman, 2011).

Lamberg and Valming (2009) investigated the link between liquidity strategies and business profitability during times of financial difficulty, as well as the relevance of core liquidity ratios. The data show that liquidity adaptation tactics have no meaningful influence on profitability. In the aftermath of the financial crisis, short-term borrowing and faster usage of liquidity have a positive impact on ROA. It is also suggested that the impact of the liquidity ratio remained stable over the research period, and that the most often utilized liquidity indicator, among others, was the working capital ratio.

Shahchera (2012) investigated the effects of liquid asset holdings on Iranian bank profitability and discovered a statistically significant influence of liquidity assets on profitability. The profit of a financial institution is highly influenced by the business cycle and adversely influenced by restrictions. It is proposed that relaxing regulatory restraints will increase profitability.

According to Aminu (2012), a firm's steady development and survival are connected to the preservation of an optimal balance between liquidity and profitability in accordance with the firm's plans and primary objectives.

According to Saluja and Kumar (2012), there is a negative link between profitability and liquidity, and there is a need to maintain equilibrium between both dimensions because if a business attempts to optimize profitability, its capacity to satisfy liabilities falls.

in different studies of this subject, it is determined that the literature is inconclusive and that further evidence on this critical problem in financial management is required. The goal is to add to the current research by examining the effects of firm-specific and macroeconomic drivers of profitability and liquidity on the profitability of Modaraba enterprises operating in Pakistan.

\section{Hypotheses}

The following hypotheses are formed based on the preceding literature review.

H1: Modaraba firm specific factors have a significant impact on efficiency of Modaraba Companies.

H2: Macroeconomic factors have a significant impact on efficiency of Modaraba Companies.

Variable Addressed in the Study

\begin{tabular}{|c|c|c|c|}
\hline Sr. & Variable & Abbr. & Calculation \\
\hline 1 & $\begin{array}{l}\text { Technical Efficiency } \\
\text { Score (CRS) }\end{array}$ & TE & Calculated via DEA \\
\hline
\end{tabular}




\begin{tabular}{|c|c|c|c|c|}
\hline 2 & DV & $\begin{array}{lr}\text { Pure } & \text { Technical } \\
\text { Efficiency } & \text { Score } \\
\text { (VRS) } & \end{array}$ & PTE & Calculated via DEA \\
\hline 3 & DV & $\begin{array}{l}\text { Scale } \quad \text { Efficiency } \\
\text { Score }\end{array}$ & SE & Calculated via DEA \\
\hline 4 & Other Item & $\begin{array}{l}\text { Age of the Modaraba } \\
\text { Company }\end{array}$ & AGE & $\begin{array}{l}\text { Calculated from the date of commencement of } \\
\text { Modaraba Company }\end{array}$ \\
\hline 5 & Other Item & Log of Total Assets & LTA & $\begin{array}{l}\text { Natural log of total assets as per end of the period } \\
\text { as shown in balance sheet }\end{array}$ \\
\hline 6 & Other Item & $\begin{array}{ll}\text { Number } & \text { of } \\
\text { Certificates (000) }\end{array}$ & NOC & $\begin{array}{l}\text { Outstanding certificates at end of the period as } \\
\text { shown in balance sheet }\end{array}$ \\
\hline 7 & $\begin{array}{l}\text { Efficiency } \\
\text { Ratio/Profitability } \\
\text { Ratio }\end{array}$ & Return on Equity & ROE & $\begin{array}{l}\text { (Net Profit after Tax / Total Shareholders' Equity) } \\
* 100\end{array}$ \\
\hline 8 & $\begin{array}{l}\text { Efficiency } \\
\text { Ratio/Profitability } \\
\text { Ratio }\end{array}$ & $\begin{array}{l}\text { Return on Capital } \\
\text { Employed }\end{array}$ & ROCE & $\begin{array}{l}\text { (Profit before Tax / (Total Assets - Current } \\
\text { Liabilities) } * 100\end{array}$ \\
\hline 9 & $\begin{array}{l}\text { Efficiency } \\
\text { Ratio/Profitability } \\
\text { Ratio }\end{array}$ & Return on Assets & ROA & (Net Profit after Tax / Total Assets) $* 100$ \\
\hline 10 & $\begin{array}{l}\text { Efficiency } \\
\text { Ratio/Profitability } \\
\text { Ratio }\end{array}$ & Return on Revenue & ROR & (Net income / Revenue) $* 100$ \\
\hline 11 & $\begin{array}{l}\text { Efficiency } \\
\text { Ratio/Profitability } \\
\text { Ratio }\end{array}$ & $\begin{array}{l}\text { Operating Expenses } \\
\text { to Net Income }\end{array}$ & OENI & (Operating Expense / Net Income)*100 \\
\hline 12 & $\begin{array}{l}\text { Efficiency } \\
\text { Ratio/Profitability } \\
\text { Ratio }\end{array}$ & $\begin{array}{l}\text { Management } \\
\text { Expenses }\end{array}$ & ME & (Remuneration to Advisor / Total Expenses) $* 100$ \\
\hline 13 & $\begin{array}{l}\text { Efficiency } \\
\text { Ratio/Profitability } \\
\text { Ratio }\end{array}$ & $\begin{array}{l}\text { Earning } \\
\text { Certificate }\end{array}$ & EPC & Profit after Tax / No.of Certificates \\
\hline 14 & $\begin{array}{l}\text { Liquidity } \\
\text { Ratio/Current } \\
\text { Ratio }\end{array}$ & 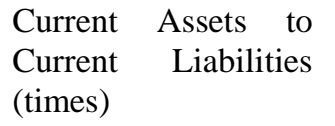 & CACL & Current Assets / Current Liabilities \\
\hline 15 & $\begin{array}{l}\text { Liquidity } \\
\text { Ratio/Current } \\
\text { Ratio }\end{array}$ & $\begin{array}{l}\text { Total Liabilities to } \\
\text { Total Assets (times) }\end{array}$ & TLTA & (Total liabilities / Total Assets) $* 100$ \\
\hline 16 & Leverage Ratio & Capital Ratio & CR & (Total Shareholders’ Equity / Total assets) $* 100$ \\
\hline 17 & Leverage Ratio & $\begin{array}{l}\text { Break Up Value Per } \\
\text { Certificate }\end{array}$ & BUVPC & $\begin{array}{l}\text { Modaraba Certificate Holders' Equity / No.of } \\
\text { Modaraba Certificates }\end{array}$ \\
\hline 18 & $\begin{array}{l}\text { Macroeconomic } \\
\text { Variable }\end{array}$ & $\begin{array}{l}\text { Gross } \quad \text { Domestic } \\
\text { Product }\end{array}$ & GDP & GDP Growth (Annual \%) \\
\hline 19 & $\begin{array}{l}\text { Macroeconomic } \\
\text { Variable }\end{array}$ & Rate of Inflation & INF & Inflation, Consumer Prices (Annual \%) \\
\hline 20 & $\begin{array}{l}\text { Macroeconomic } \\
\text { Variable }\end{array}$ & Rate of Interest & INT & $\begin{array}{l}\text { Interest Rate Spread (Lending Rate minus Deposit } \\
\text { Rate, \%) }\end{array}$ \\
\hline 21 & $\begin{array}{l}\text { Macroeconomic } \\
\text { Variable }\end{array}$ & Exchange Rate & EXC & $\begin{array}{l}\text { Official Exchange Rate (LCU per US\$, period } \\
\text { average) }\end{array}$ \\
\hline
\end{tabular}

Model Description Following research models have been used to measure the relationship among prevailing variables:

\section{Econometric Model and Variable Description}

\section{Model-1}

$\mathrm{TE}_{\mathrm{it}}=\alpha_{\mathrm{o}}+\beta_{1} \mathrm{AGE}_{\mathrm{it}}+\beta_{2} \mathrm{LTA}_{\mathrm{it}}+\beta_{3} \mathrm{NOC}_{\mathrm{it}}+\beta_{4} \mathrm{ROE}_{\mathrm{it}}+\beta_{5} \mathrm{ROCE}_{\mathrm{it}}+\beta_{6} \mathrm{ROA}_{\mathrm{it}}+\beta_{7} \mathrm{ROR}_{\mathrm{it}}+\beta_{8} \mathrm{OENI}_{\mathrm{it}}+\beta_{9} \mathrm{ME}_{\mathrm{it}}$ $+\beta_{10} \mathrm{EPC}_{\text {it }}+\beta_{11} \mathrm{CACL}_{\mathrm{it}}+\beta_{12} \mathrm{TLTA}_{\mathrm{it}}+\beta_{13} \mathrm{CR}_{\mathrm{it}}+\beta_{14} \mathrm{BUVPC}_{\mathrm{it}}+\beta_{15} \mathrm{GDP}_{\mathrm{it}}+\beta_{16} \mathrm{INF}_{\mathrm{it}}+\beta_{17} \mathrm{INT}_{\mathrm{it}}$ $+\beta_{18} \mathrm{EXC}_{\mathrm{it}}+\varepsilon_{\mathrm{it}}$

\section{Model-2}

$\mathrm{PTE}_{\mathrm{it}}=\alpha_{\mathrm{o}}+\beta_{1} \mathrm{AGE}_{\mathrm{it}}+\beta_{2} \mathrm{LTA}_{\mathrm{it}}+\beta_{3} \mathrm{NOC}_{\mathrm{it}}+\beta_{4} \mathrm{ROE}_{\mathrm{it}}+\beta_{5} \mathrm{ROCE}_{\mathrm{it}}+\beta_{6} \mathrm{ROA}_{\mathrm{it}}+\beta_{7} \mathrm{ROR}_{\mathrm{it}}+\beta_{8}$ 
$\mathrm{OENI}_{\mathrm{it}}+\beta_{9} \mathrm{ME}_{\mathrm{it}}+\beta_{10} \mathrm{EPC}_{\mathrm{it}}+\beta_{11} \mathrm{CACL}_{\mathrm{it}}+\beta_{12} \mathrm{TLTA}_{\mathrm{it}}+\beta_{13} \mathrm{CR}_{\mathrm{it}}+\beta_{14} \mathrm{BUVPC}_{\mathrm{it}}+\beta_{15}$ $\mathrm{GDP}_{\text {it }}+\beta_{16} \mathrm{INF}_{\text {it }}+\beta_{17} \mathrm{INT}_{\mathrm{it}}+\beta_{18} \mathrm{EXC}_{\mathrm{it}}+\varepsilon_{\mathrm{it}}$

\section{Model-3}

$\mathrm{SE}_{\mathrm{it}}=\alpha_{\mathrm{o}}+\beta_{1} \mathrm{AGE}_{\mathrm{it}}+\beta_{2} \mathrm{LTA}_{\mathrm{it}}+\beta_{3} \mathrm{NOC}_{\mathrm{it}}+\beta_{4} \mathrm{ROE}_{\mathrm{it}}+\beta_{5} \mathrm{ROCE}_{\mathrm{it}}+\beta_{6} \mathrm{ROA}_{\mathrm{it}}+\beta_{7} \mathrm{ROR}_{\mathrm{it}}+\beta_{8}$ $\mathrm{OENI}_{\mathrm{it}}+\beta_{9} \mathrm{ME}_{\mathrm{it}}+\beta_{10} \mathrm{EPC}_{\mathrm{it}}+\beta_{11} \mathrm{CACL}_{\mathrm{it}}+\beta_{12}$ TLTA $_{\mathrm{it}}+\beta_{13} \mathrm{CR}_{\mathrm{it}}+\beta_{14} \mathrm{BUVPC}_{\mathrm{it}}+\beta_{15}$ $\mathrm{GDP}_{\mathrm{it}}+\beta_{16} \mathrm{INF}_{\mathrm{it}}+\beta_{17} \mathrm{INT}_{\mathrm{it}}+\beta_{18} \mathrm{EXC}_{\mathrm{it}}+\varepsilon_{\mathrm{it}}$

\section{Population and Sample Selection}

The study covers ten years period from 2010 to 2019. The population for the study was 25Modaraba companies currently operating in Pakistan, whereas only one company named Awwal Modarba commenced in 2014 which do not complete the tenure of the study duration of 10 years, so it was dropped and analyses was done for remaining 24 modaraba companies.

\section{Data Source and Statistics}

To fulfill the above-mentioned performance assessment goal, a non-parametric linear programming-based frontier methodology known as Data Envelopment Analysis (DEA) was applied. The benefit of employing DEA over its nearest rival technique Stochastic Frontier Analysis (SFA) is that no functional relationship between inputs and outputs or weights of inputs and outputs are required. Chambers et al, (2018).SFA efficiency ratings are partly determined by how effectively the selected functional form reflects the underlying production function. This is not the case with the DEA.DEA may accept numerous inputs and numerous outputs at the same time to calculate relative efficiency and produce a scalar assessment of overall performance. It can also study changes in efficiency because of input savings and determine if the causes for such changes are increases in scale (scale efficiency) or management techniques (pure technical efficiency). We employed a directional distance-based meta-frontier production function that has been effectively employed by other authors to conduct an in-depth investigation of the efficiency across different ownership groups. Bogetoft et al (2019); Chambers et al.(2010); Fare and Grosskopf (2011); Huang et al.(2012); Ray et al (2013); Yao et al.(2014).

\section{Selection of Input and Output Variables for DEA Scores Calculation}

Because the DEA efficiency results are highly influenced by sample size, the number and selection of input and output variables, some consideration of sample size adequacy is justified here. The sample size used in this study is consistent with the numerous guidelines available in the DEA literature. Cooper et al (2007) propose two such rules that may be stated together.

- The first rule of thumb states that the number of DMUs should be greater than equal to the product of inputs and outputs.

- While the second rule states that the number of DMUs should be at least three times the sum of several input and output variables.

Given that in this study number of inputs are 3 and number of outputs are also 3, the sample size used in the present study exceeds the above-cited criterion. Further, the number of DMUs in each sub-sector also fulfills the desirable size, as suggested by the above-mentioned rules of thumb to obtain sufficient discriminatory power.

\begin{tabular}{ll|lll}
\hline INPUT & Reference & OUTPUT & Reference \\
\hline Total Equity & ADA, et al.,(2014) & $\begin{array}{l}\text { Long-Term } \\
\text { Investments }\end{array}$ & Elyasiani, et al., (2012) \\
\hline Total Liabilities & $\begin{array}{l}\text { Adjei-Frimpong, et } \begin{array}{l}\text { al., } \\
\text { (2013) }\end{array} \\
\begin{array}{l}\text { Profit/(Loss) } \\
\text { Taxation }\end{array}\end{array}$ & after & Drake, et al.,(2006). \\
\hline Total Assets & Ramanathan, et al., (2007). & Earning Per Certificate & Zohdi, et al., (2012). \\
\hline
\end{tabular}

The study compiled secondary data from a database maintained by the State Bank of Pakistan's (SBP) statistical division, as well as published financial statements also consulted for each 
modaraba company from 2010 to 2019, which were analyzed for descriptive statistics, correlation, multiple regressions, and other statistical tests.

\section{Results and Analysis}

Descriptive Analysis of Variables
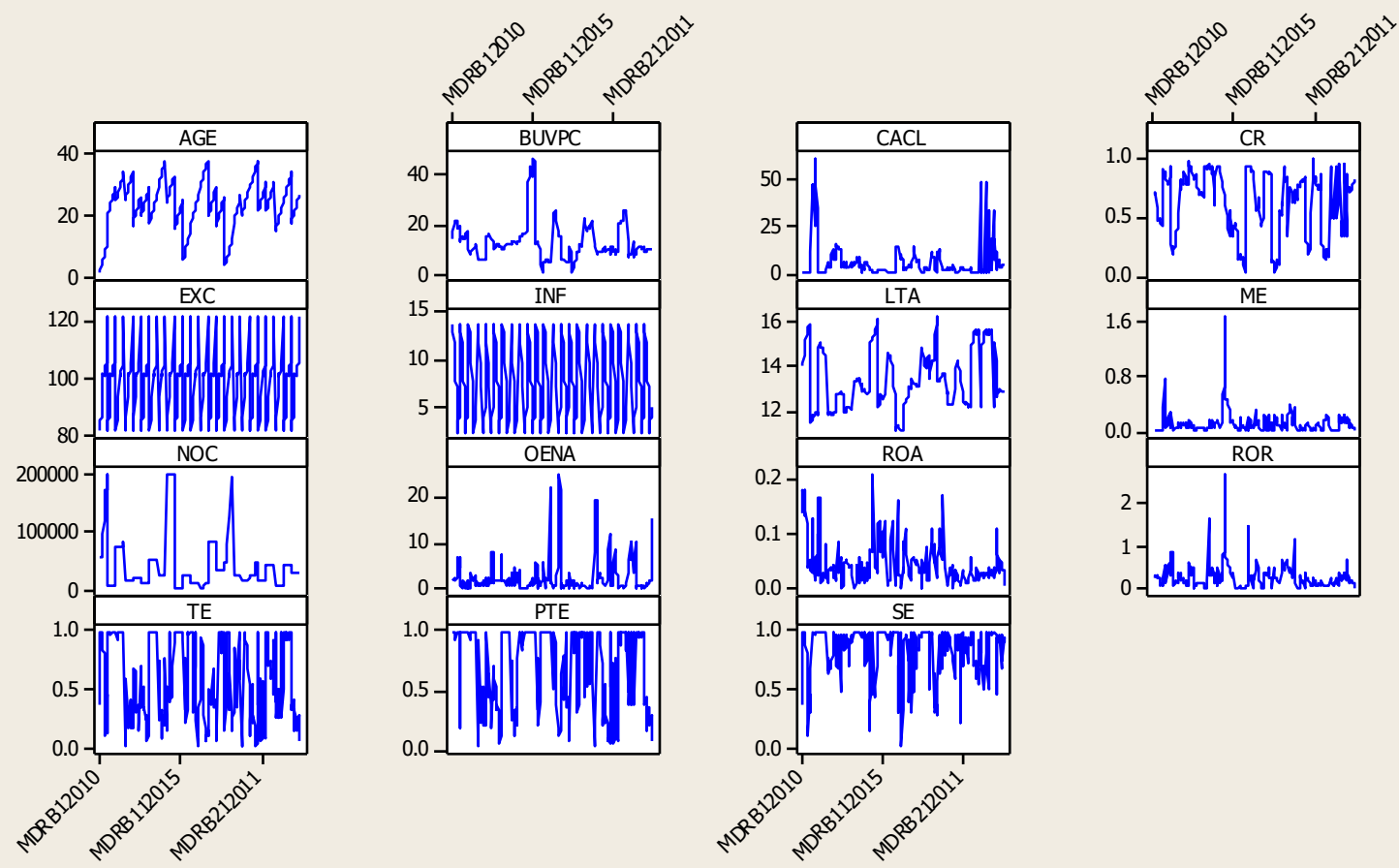

Figure 1 Line plot

Table 1 Descriptive Statistics

\begin{tabular}{lllllll}
\hline Variable & Mean & SD & Max & Min & Skewness & Kurtosis \\
\hline AGE & 23.63 & 7.58 & 38.00 & 2.00 & -0.69 & 3.34 \\
BUVPC & 13.31 & 7.88 & 46.72 & 0.33 & 1.95 & 8.04 \\
CACL_W & 5.16 & 5.61 & 21.81 & 0.47 & 1.68 & 5.03 \\
CR & 0.63 & 0.27 & 1.00 & 0.02 & -0.64 & 2.19 \\
EXC & 98.42 & 11.42 & 121.82 & 81.71 & 0.32 & 2.58 \\
INF & 7.85 & 3.84 & 13.65 & 2.53 & 0.19 & 1.59 \\
LTA & 13.47 & 1.33 & 16.32 & 11.07 & 0.32 & 2.02 \\
ME_W & 0.10 & 0.09 & 0.34 & 0.01 & 1.13 & 3.39 \\
NOC_W & 44125.72 & 47707.50 & 195600.00 & 5863.00 & 2.12 & 6.85 \\
OENI_W & 2.24 & 2.35 & 8.94 & 0.29 & 1.82 & 5.30 \\
PTE & 0.71 & 0.33 & 1.00 & 0.03 & -0.57 & 1.72 \\
ROA & 0.05 & 0.04 & 0.21 & 0.00 & 1.79 & 6.56 \\
ROR_W & 0.26 & 0.19 & 0.70 & 0.03 & 0.85 & 2.82 \\
SE & 0.85 & 0.21 & 1.00 & 0.02 & -1.57 & 4.74 \\
TE & 0.60 & 0.34 & 1.00 & 0.02 & -0.03 & 1.47 \\
TLTA & 0.35 & 0.27 & 0.98 & 0.02 & 0.76 & 2.39 \\
\hline
\end{tabular}

The variable CACL, EPC, ME, NOC, OENI, ROCE, ROE and ROR were highly dispersed and having outliers. These variables were winsorized at 5\% level of significance. Table 1 show the result of descriptive statistics and it provide the detail of the variable in the form of mean, standard deviation, maximum, minimum, skewness and kurtosis. The maximum value for PTE, 
SE and TE was 1 and the minimum value was $0.03,0.02$ and 0.02 for each efficiency measure respectively. The overall mean efficiency using PTE, SE and TE was $0.71,0.85,0.60$ respectively Modaraba Companies specific determinants have an average value of 23.63 for age, 13.31 for BUVPC, 5.16 for CALC, 0.63 for CR, 98.42 for EXC, 7.85 for INF, 13.47 for LTA, 0.10 for ME W, 44125.72 for NOC_W, 2.24 for OENI_W, 0.71 for PTE, 0.05 for ROA, 0.26 for ROR_W, 0.85 for SE, 0.60 for TE and 0.35 for TLTA.

Table 2 Correlation and Multicollinearity Diagnostic

\begin{tabular}{|c|c|c|c|c|c|c|c|c|c|c|c|c|c|c|c|}
\hline & & BU & CA & & EX & & & & $\mathrm{NO}$ & $\mathrm{OE}$ & & RO & RO & & \\
\hline & AGE & VPC & CL & CR & $\mathrm{C}$ & INF & LTA & ME & $\mathrm{C}$ & NI & PTE & A & $\mathrm{R}$ & SE & TE \\
\hline $\mathrm{BU}$ & & & & & & & & & & & & & & & \\
\hline VP & -0.09 & & & & & & & & & & & & & & \\
\hline $\mathrm{C}$ & 0.18 & & & & & & & & & & & & & & \\
\hline & & - & & & & & & & & & & & & & \\
\hline CA & 0.02 & 0.15 & & & & & & & & & & & & & \\
\hline CL & (0.71 & 0.02 & & & & & & & & & & & & & \\
\hline & 0.12 & -0.2 & & & & & & & & & & & & & \\
\hline & (0.06 & 0.00 & 0.55 & & & & & & & & & & & & \\
\hline CR & ) & ) & 0.00 & & & & & & & & & & & & \\
\hline & & & & - & & & & & & & & & & & \\
\hline EX & 0.36 & 0.02 & -0.1 & 0.04 & & & & & & & & & & & \\
\hline $\mathrm{C}$ & 0.00 & 0.76 & 0.11 & 0.55 & & & & & & & & & & & \\
\hline & & - & & & - & & & & & & & & & & \\
\hline & -0.35 & 0.03 & 0.06 & 0.02 & 0.84 & & & & & & & & & & \\
\hline INF & 0.00 & 0.69 & 0.37 & 0.76 & 0.00 & & & & & & & & & & \\
\hline & & & - & - & & - & & & & & & & & & \\
\hline LT & $\begin{array}{l}-0.18 \\
0.00\end{array}$ & 0.13 & 0.38 & 0.56 & 0.06 & $\begin{array}{l}0.05 \\
0.40\end{array}$ & & & & & & & & & \\
\hline & & & 0.00 & $\begin{array}{l}0.00 \\
-\end{array}$ & $\begin{array}{l}0.31 \\
-\end{array}$ & & & & & & & & & & \\
\hline & 0.13 & 0.11 & 0.23 & 0.03 & 0.17 & 0.12 & 0.11 & & & & & & & & \\
\hline $\mathrm{ME}$ & 0.05 & 0.10 & 0.00 & 0.65 & 0.01 & 0.05 & 0.10 & & & & & & & & \\
\hline NO & -0.16 & 0.03 & 0.22 & 0.08 & 0.09 & 0.09 & 0.62 & 0.23 & & & & & & & \\
\hline $\mathrm{C}$ & 0.01 & 0.64 & 0.00 & 0.19 & 0.14 & 0.15 & 0.00 & 0.00 & & & & & & & \\
\hline & & - & - & & & - & - & & - & & & & & & \\
\hline $\mathrm{OE}$ & 0.03 & 0.14 & 0.17 & 0.02 & 0.19 & 0.14 & 0.04 & -0.5 & 0.14 & & & & & & \\
\hline NI & 0.65 & 0.03 & 0.01 & 0.73 & 0.00 & 0.04 & 0.50 & 0.00 & 0.03 & & & & & & \\
\hline & & & & - & & - & & & & - & & & & & \\
\hline PT & -0.22 & 0.22 & 0.09 & 0.15 & 0.06 & 0.03 & 0.29 & 0.22 & 0.27 & 0.29 & & & & & \\
\hline E & 0.00 & 0.00 & $\begin{array}{l}0.17 \\
-\end{array}$ & $\begin{array}{l}0.02 \\
-\end{array}$ & $\begin{array}{l}0.40 \\
-\end{array}$ & 0.64 & 0.00 & 0.00 & 0.00 & $\begin{array}{l}0.00 \\
-\end{array}$ & & & & & \\
\hline RO & -0.33 & 0.36 & 0.02 & 0.06 & 0.18 & 0.12 & 0.06 & 0.25 & 0.14 & 0.37 & 0.3 & & & & \\
\hline A & 0.00 & 0.00 & 0.81 & 0.39 & 0.01 & 0.07 & 0.38 & 0.00 & 0.03 & 0.00 & 0.00 & & & & \\
\hline RO & -0.05 & 0.06 & 0.26 & 0.23 & 0.15 & 0.1 & 0.08 & 0.55 & 0.38 & 0.52 & 0.27 & 0.52 & & & \\
\hline $\mathrm{R}$ & 0.47 & 0.39 & 0.00 & 0.00 & 0.02 & 0.12 & 0.23 & 0.00 & 0.00 & 0.00 & 0.00 & 0.00 & & & \\
\hline & & & & - & - & & - & - & - & - & - & & - & & \\
\hline & 0.12 & 0.04 & 0.08 & 0.12 & 0.02 & 0.07 & 0.15 & 0.06 & 0.41 & 0.17 & 0.03 & 0.08 & 0.08 & & \\
\hline SE & 0.05 & 0.51 & 0.23 & 0.06 & 0.74 & 0.31 & 0.02 & 0.33 & $\begin{array}{l}0.00 \\
-\end{array}$ & $\begin{array}{l}0.01 \\
-\end{array}$ & 0.65 & 0.20 & 0.23 & & \\
\hline & -0.11 & 0.21 & 0.13 & -0.2 & 0.02 & 0.02 & 0.16 & 0.16 & 0.01 & 0.35 & 0.84 & 0.31 & 0.2 & 0.49 & \\
\hline TE & 0.08 & 0.00 & 0.04 & 0.00 & 0.79 & 0.72 & 0.01 & 0.01 & 0.93 & 0.00 & 0.00 & 0.00 & 0.00 & 0.00 & \\
\hline TL & -0.11 & 0.19 & 0.63 & $\overline{0} .96$ & 0.02 & 0.00 & 0.49 & 0.00 & 0.06 & 0.02 & 0.07 & 0.03 & 0.25 & 0.10 & 0.12 \\
\hline TA & 0.08 & 0.00 & 0.00 & 0.00 & 0.75 & 0.97 & 0.00 & 0.95 & 0.35 & 0.76 & 0.27 & 0.60 & 0.00 & 0.13 & 0.07 \\
\hline VI & 1.61 & 1.24 & 1.89 & 2.57 & 3.56 & 3.41 & 2.87 & 1.92 & 2.58 & 1.60 & & 2.02 & 2.79 & & \\
\hline $\mathbf{F}$ & 1 & 2 & 6 & 5 & 7 & 6 & 5 & 3 & 2 & 3 & - & 5 & 6 & - & - \\
\hline
\end{tabular}


Table 2 presents correlation matrix along significant level in bracket with VIF for each profitability measures of Modaraba Companies specific and macroeconomic variables. Concerning Modaraba Companies specific variables, the results indicate that capital ratio CR and Operating Expenses to Net Income OENI had negative correlation with PTE, SE and TE. Whereas the Age had a negative correlation with PTE and TE and positive correlation with SE, moreover Exchange Rate EXC, Log of Total Assets LTA and Management Expenses ME had negative correlation with SE and positive correlation with PTE and TE. Furthermore, Inflation INF had negative correlation with PTE and positive correlation with SE and TE. Moreover, Number of Certificates NOC had negative correlation with SE and TE and positive correlation with PTE. 
Table 3 Regression Modeling

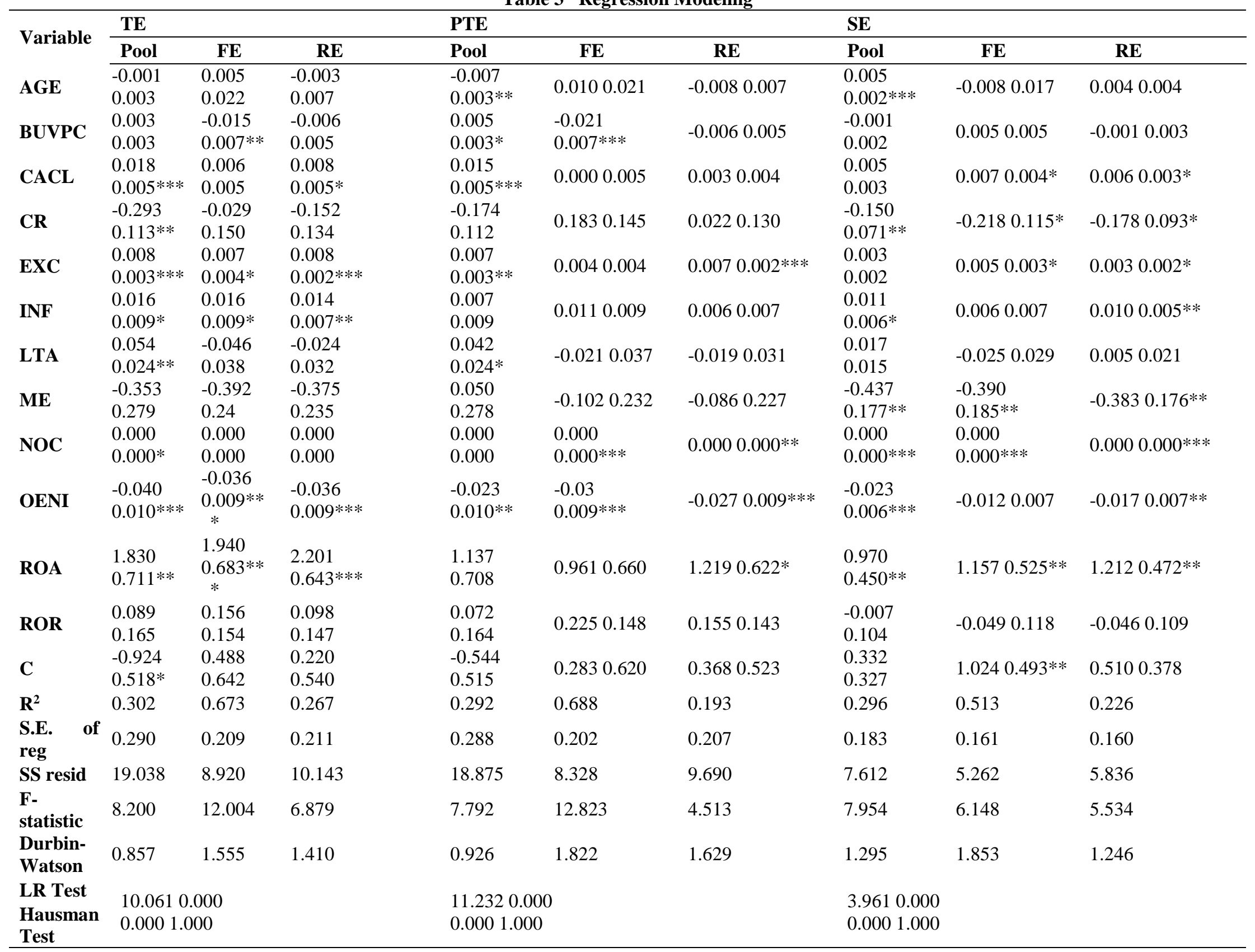

Pool= Pooled OLS, FE=Fixed Effect, RE=Random Effect 


\section{Regression Analysis}

Panel data regression modeling have three different model including, Pool regression model, Fixed effect model and random effect model for TE as dependent variable. Also, for PTE and SE, we have used pool, fixed and random effects models. If we check TE then we can see likelihood ratio is significant which shows that fixed effect is better than pooled effect, Value of Hausman test is 0.00 , which shows that random effects model is better than fixed effect. In the second level, fixed effect is better again. Fixed effect is better than pooled effect and value of Hausman test is 0.00 which shows that random effect is best suited for this model, as compared to fixed effect. For SE, the fixed effect model is better than pooled effect and the value of Hausman test is 0.00 which shows that random effect is suitable for $\mathrm{SE}$ as compared to the fixed effect. From here if we estimate for SE model made for it values are lesser then other two DV models. If we want to suggest overall then we can say SE is working good and best fit, because its criterion is lesser then all other. Furthermore, the best suited model will be random effect model. The results with $\mathrm{SE}$ as dependent variable have minimum standard error of the regression model and similarly the sum of square S.S of residual is also minimum for SE, so we found the model with SE as the best selected model. The value of LR test for SE shows that the random effect model is better than the Pool estimation. And the p-value of Hausman test shows that the random effect model is highly significant then fixed effect model. The best fitted model for SE is random effect model and, in this model, the CALC_W, CR, EXC, INF, ME_W, NOC_W, OENI_W and ROA is found significant.

\section{Conclusions and Recommendations}

In the current study the financial performance of Modaraba Companies of Pakistan was analyzed in depth by using the determinants of its profitability. The financial performance of Modaraba Companies was measured based on three dependent variables calculated via data envelopment analysis DEA: technical efficiency TE, pure technical efficiency PTE, and scale efficiency SE. Using these three variables user can confine the key operations of Modaraba Companies.

The results of this study indicate that performance determinant variables concerning specifically to Modaraba Companies, the results indicate that $\mathrm{CR}$ and OENI had negative correlation with PTE, SE and TE. Whereas the age had a negative correlation with PTE and TE and positive correlation with SE, moreover EXC, LTA and ME had negative correlation with SE and positive correlation with PTE and TE. Furthermore, INF had negative correlation with PTE and positive correlation with SE and TE. Moreover, NOC had negative correlation with SE and TE and positive correlation with PTE.

In the early modern period, Pakistan's Modaraba Companies has been enthralled to enhancements in design and size with the help of some significant reform procedures and a powerful macroeconomic basis. Pakistan's Modaraba Companies have observed a swift because of the huge transformation of aggregated resources from public to private firms, and this largely resulted in minimized resource concentration in this industry. Denationalization is the chief cause for these huge enhancements and has influenced the presentation of insurance firm design in the future. Regardless of the denationalization of the insurance firm, the intercession wave has not been minimized.

The outcomes of the given research are concentrated on the Modaraba Companies. And these outcomes can be helpful for the financial support seekers for their business entities and provide an important direction to the administrators to effectively utilize the assets as well as resources in an extra effective manner. Moreover, for the authenticity and reliability of outcome, it is suggested that analysts can enlarge the data gathering and compare the Pakistani Modaraba Companies sector to other nation's Modaraba Companies sector to better understand the link among variables both external and internal. Additionally, the analyst can also lead necessary 
study comprising contrast conduct elements that may affect the insurer advantage. Future research can be conducted with other verity of Modaraba Companies specific and macroeconomic variables along with extension of larger time for the study.

\section{References}

ADA, A. A., \& DALKILIÇ, N. (2014). Efficiency Analysis in Islamic Banks: A Study for Malaysia and Turkey. Journal of Brsa Banking \& Financial Markets, 8(1).

Adjei-Frimpong, K. (2013). Bank efficiency and bank competition: empirical evidence from Ghana's banking industry (Doctoral dissertation, Lincoln University).

Al-Jarhi, M. A. (2004). Islamic banking and finance: Philosophical underpinnings. Islamic Banking and Finance: Fundamentals and Contemporary Issues. Islamic Research and Training Institue, Seminar Proceedings Nr. 47: 13/25, Brunei.

Aminu, Y. (2012). A Nexus between Liquidity/Profitability Trade-Offs for Working Capital Management in Nigerias Manufacturing Sector. International Journal of Arts and Commerce, 1(6),55-58.

Bashir, A. (2001). Profit-sharing contracts and investment under asymmetric information. Research in Middle East Economics, 1, 173-186.

Bashir, A. H. M. (1996). Investment under profit-sharing contracts: The adverse selection case. Managerial Finance, 22(5/6), 48-58.

Bhunia, A., Bagchi, B., \& Khamrui, B. (2012). The Impact of Liquidity on Profitability: A Case Study of FMCG Companies in India. Research and Social practices in Social Sciences, 7(2), 44-58.

Bordeleau, É., \& Graham, C. (2010). The impact of liquidity on bank profitability. Bank of Canada Working Paper.

Chamberlain, T. W. (2009). Firm Survival: Liquidity versus Profitability. Retrieved from: http://faculty.buffalostate.edu/joth/pk2009/Site/program_files/Chamberlain.pdf +

Cooper, W.W., Seiford, L.M. and Tone, K. (Eds) (2007), Data Envelopment Analysis: A Comprehensive Text with Models, Applications, References and DEA-solver Software, Springer Science pBusiness Media B.V, Boston, MA.

Drake, L., Hall, M. J., \& Simper, R. (2006). The impact of macroeconomic and regulatory factors on bank efficiency: A non-parametric analysis of Hong Kong's banking system. Journal of Banking \& Finance, 30(5), 1443-1466.

Drehmann, M., \& Nikolaou, K. (2012). Funding liquidity risk: definition and measurement. Journal of Banking \& Finance.

Elyasiani, E., \& Wang, Y. (2012). Bank holding company diversification and production efficiency. Applied Financial Economics, 22(17), 1409-1428.

Haque, N., \& Mirakhor, A. (1986). Optimal Profit-Sharing Contracts and Investment. IMF Working Paper, WP/86/12, IMF, Washington, DC.

Holz, C. A. (2002). The impact of the liability-asset ratio on profitability in China's industrial state-owned enterprises. China Economic Review, 13(1), 1-26.

Iqbal, Z., \& Lewis, M. K. (2009). An Islamic Perspective on Governance. USA, Massachusetts: Edward Elgar Publishing Inc.

Jouaber, K., \& Mehri, M. (2012a). A theory of profit-sharing ratio under adverse selection: The case of Islamic venture capital. Available at SSRN Electronic Journal. doi: $10.2139 /$ ssrn.1928861.

Khan, W. M. (1985). Towards an Interest-free Economic System. Islamic economic series, the Islamic foundation, Leicester, UK.

Lamberg, S., \&Valming, S. (2009). Impact of Liquidity Management on Profitability a study of the adaptation of liquidity strategies in a financial crisis, master dissertation, Umea School of Business.

Lartey, V. C., Antwi, S., \&Boadi, E. K. (2013). The Relationship between Liquidity and Profitability of Listed Banks in Ghana. International Journal of Business and Social 
Science, 4(3).

Mathuva, D. (2009). The influence of working capital management components on corporate profitability: a survey on Kenyan listed firms. Research Journal of Business Management, $3(1), 1-11$.

Nikolaou, K. (2009). Liquidity (risk) Concepts: definitions and interactions. European Central Bank, working paper series No. 1008. Retrieved from: https://www.ecb.eu/pub/pdf/scpwps/ecbwp1008.pdf

Ramanathan, R. (2007). Performance of banks in countries of the Gulf Cooperation Council. International journal of productivity and performance management, 56(2), 137154.

Saleem, Q., \& Rehman, R. U. (2011). Impact of Liquidity Ratios on Profitability. Interdisciplinary Journal of Research in Business, 1(7), 95-98.

Saluja, P., \& Kumar, P. (2012). Liquidity and Profitability Trade Off. International Journal of Advanced Research in Management and Social Sciences, 1(3), 77-84.

Samadzadeh, N., \& Melander, H. (2012). The Implications of Agency Theory on Mudarabah and Musharakah Agreements: A Comparison with Conventional Debt. Stockholm School of Economics Department of Finance Thesis in Finance.

Sapuan, N. M. (2016). An Evolution of Mudarabah Contract: A Viewpoint from Classical and Contemporary Islamic Scholars. Procedia Economics and Finance 35, 349 - 358.

Sarker, A. (2000). Islamic Business Contracts, Agency Problem and Theory of the Islamic Firm. International Journal of Islamic Financial Services 1(2).

Shahchera, M. (2012). The Impact of Liquidity Asset on Iranian Bank Profitability. International Conference on Management, Behavioral Sciences and Economics Issues, Penang, Malaysia, 131-135.

Zohdi, M., Marjani, A. B., Najafabadi, A. M., Alvani, J., \&Dalv, M. R. (2012). Data envelopment analysis (DEA) based performance evaluation system for investment companies: Case study of Tehran Stock Exchange. African Journal of Business Management, 6(16), 5573-5577. 


\begin{tabular}{|c|c|c|}
\hline \multicolumn{3}{|c|}{ Appendix } \\
\hline $\mathrm{Sr} \#$ & DMU TITLE & Date of Commencement \\
\hline 1 & Allied Rental Modaraba & 2007 \\
\hline 2 & Awwal Modarba & 2014 \\
\hline 3 & B.F. Modaraba & 1989 \\
\hline 4 & B.R.R. Guardian Modaraba & 1984 \\
\hline 5 & Crescent Standard Modaraba & 1984 \\
\hline 6 & First Al-Noor Modaraba & 1992 \\
\hline 7 & First Elite Capital Modaraba & 1989 \\
\hline 8 & First Equity Modaraba & 1991 \\
\hline 9 & First Fidelity Leasing Modaraba & 1980 \\
\hline 10 & First Habib Modaraba & 1985 \\
\hline 11 & First Imrooz Modaraba & 1993 \\
\hline 12 & First National Bank Modaraba & 2003 \\
\hline 13 & First Pak Modaraba & 1991 \\
\hline 14 & First Paramount Modaraba & 1980 \\
\hline 15 & First Prudential Modaraba & 1989 \\
\hline 16 & First Punjab Modaraba & 1992 \\
\hline 17 & First Treet Manufacturing Modaraba & 2005 \\
\hline 18 & First UDL Modaraba & 1991 \\
\hline 19 & IBL Modaraba & 1989 \\
\hline 20 & KASB Modaraba & 1980 \\
\hline 21 & Modaraba Al-Mali & 1987 \\
\hline 22 & Orix Modarba & 1987 \\
\hline 23 & Popular Islamic Modarba & 1994 \\
\hline 24 & Sindh Modarba & 1984 \\
\hline 25 & Trust Modaraba & 1991 \\
\hline
\end{tabular}




\section{Frequency Table and Graph of Input \& Output Variables for DEA Analysis}
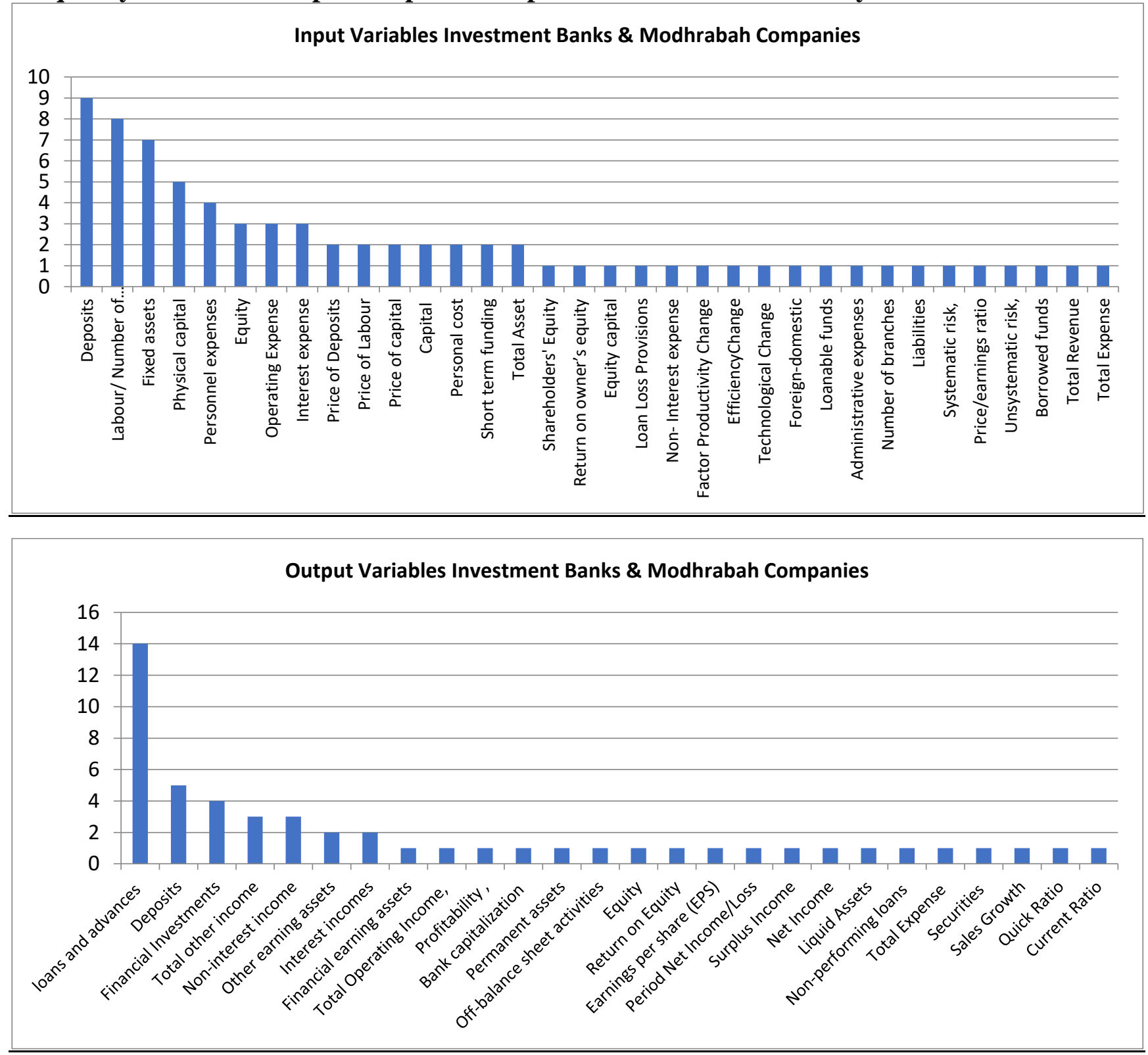

\begin{tabular}{|l|l|l|l|}
\hline Input & Frequency & Output & Frequency \\
\hline Deposits & 9 & loans and advances & 14 \\
\hline Labor/ Number of employees & 8 & Deposits & 5 \\
\hline Fixed assets & 7 & Financial Investments & 4 \\
\hline Physical capital & 5 & Total other income & 3 \\
\hline Personnel expenses & 4 & Non-interest income & 3 \\
\hline Equity & 3 & Other earning assets & 2 \\
\hline Operating Expense & 3 & Interest incomes & 2 \\
\hline Interest expense & 3 & Financial earning assets & 1 \\
\hline Price of Deposits & 2 & Total Operating Income, & 1 \\
\hline Price of Labour & 2 & Profitability, & 1 \\
\hline Price of capital & 2 & Bank capitalization & 1 \\
\hline Capital & 2 & Permanent assets & 1 \\
\hline Personal cost & 2 & Off-balance sheet activities & 1 \\
\hline & & 457 &
\end{tabular}




\begin{tabular}{|l|l|l|l|} 
Short term funding & 2 & Equity & 1 \\
\hline Total Asset & 2 & Return on Equity & 1 \\
\hline Shareholders' Equity & 1 & Earnings per share (EPS) & 1 \\
\hline Return on owner's equity & 1 & Period Net Income/Loss & 1 \\
\hline Equity capital & 1 & Surplus Income & 1 \\
\hline Loan Loss Provisions & 1 & Net Income & 1 \\
\hline Non- Interest expense & 1 & Liquid Assets & 1 \\
\hline Factor Productivity Change & 1 & Non-performing loans & 1 \\
\hline EfficiencyChange & 1 & Total Expense & 1 \\
\hline Technological Change & 1 & Securities & 1 \\
\hline Foreign-domestic & 1 & Sales Growth & 1 \\
\hline Loanable funds & 1 & Quick Ratio & 1 \\
\hline Administrative expenses & 1 & Current Ratio & 1 \\
\hline Number of branches & 1 & & \\
\hline Liabilities & 1 & & \\
\hline Systematic risk, & 1 & & \\
\hline Price/earnings ratio & 1 & & \\
\hline Unsystematic risk, & 1 & & \\
\hline Borrowed funds & 1 & & \\
\hline Total Revenue & 1 & & \\
\hline Total Expense & 1 & & \\
\hline
\end{tabular}

\section{Sr Country \\ \# / Region}

1 Turkey

Financial

Period Analyzed

Input Parameters

Deposits, Fixed Assets, Shareholders' Equity,Personnel Expenses

$2 \quad$ Hong

Kong

3 China
1993-2000

1995 to 2001 Labor, Deposits

Personal Expense,Other Operating Expense,Loan Loss Provisions

Interest expense, price of deposits, price of labor, price of capital

$\begin{aligned} & \text { Output } \\ & \text { Parameters }\end{aligned}$
Financial
assets,

Total $r$ Operating
Income,
Loans

Capital, Net

income, commission income, Total other income

Loans, deposits, non-interest income

Profitability, Bankcapitalization, Loanratio, Return

\section{Reference}

Arslan, B. G., \&Ergec, E. H. (2010). The efficiency of participation and conventional banks in Turkey: using data envelopment analysis. International Research Journal of Finance and Economics, 57, 156-168.

interest Drake, L., Hall, M. J., \& Simper, R. (2006). The impact of macroeconomic and regulatory factors on bank efficiency: A nonparametric analysis of Hong Kong's banking system. Journal of Banking \& Finance, 30(5), 1443-1466.

Xiaogang, C., Skully, M., \& Brown, K. (2005). Banking efficiency in China: Application of DEA to preand post-deregulation eras: 19932000. China

Economic Review, 16(3), 229-245.

Aysan, A. F., \& Ceyhan, Ş. P. (2008). What determines the banking sector performance in 
5 Sri

Lanka

2003 to 2007

6 Brazil 2000-2004

8 European 1992-1997 union

Bahrain,
Kuwait,
Saudi,

UAE

2000-2004
Technological

Change, Foreign-

domestic

loanable

physical capital and personal cost

Fixed

assets,

Deposits,Short term

funding, Equity,

Personnel expenses

Price of labor, Price of capital,Price ofdeposits,Operating

costs + interest expenses

on Equity

Personnel expenses, expenses, Number of employees, Number of branches

Loans, Other earning assets

Equity (ROE)

Loans (All forms of performing and nonperforming loans),Deposits ,Financial Investments

9 Saudia 2003-2008

Operating expenses, Equity capital, and deposits

10 Tehran Oct,Nov,Dec beta index or 2010

11 Ghana

$2001-2010$

12 Turkey systematic risk, sigma index or unsystematic risk, price/earnings ratio $(\mathrm{P} / \mathrm{E})$, return on owners' equity, and total assets

Deposits, Liabilities,labor, Capital expenses to fixed assets, Interest expenses

Labor, Borrowed funds, Physical capital
Earnings per share (EPS), sales growth, current ratio, quick ratio, and net income.
Loans, Demand and time deposits, Investments

Total loans globalized financial markets? The case of Turkey. Physica A: Statistical Mechanics and its Applications, 387(7), 1593-1602.

Wanniarachchige, M. K., \& Suzuki, Y. (2010). Bank competition and efficiency: The case of Sri Lanka. Asia Pacific World, 1(1), 117-131.

Wanke, P., \& Barros, C. (2014). Two-stage DEA: An application to major Brazilian banks. Expert systems with applications, 41(5), 2337-2344.

Ramanathan, R. (2007). Performance of banks in countries of the Gulf Cooperation Council. International journal of productivity and performance management, 56(2), 137-154.

Cavallo, L., \& Rossi, S. P. (2002). Do environmental variables affect the performance and technical efficiency of the European banking systems? A parametric analysis using the stochastic frontier approach. The European Journal of Finance, 8(1), 123-146.

AlKhathlan, K., \& Malik, S. A. (2010). Are Saudi banks efficient? Evidence using data envelopment analysis (DEA). International journal of economics and finance, 2(2), 53-58.

Zohdi, M., Marjani, A. B., Najafabadi, A. M., Alvani, J., \&Dalv, M. R. (2012). Data envelopment analysis (DEA) based performance evaluation system for investment companies: Case study of Tehran Stock Exchange. African Journal of Business Management, 6(16), 5573-5577.

Adjei-Frimpong, K. (2013). Bank efficiency and bank competition: empirical evidence from Ghana's banking industry (Doctoral dissertation, Lincoln University).

Alpay, S., \& Hassan, M. K. (2007, November). A comparative efficiency analysis of interest free financial institutions and conventional banks: A case study on Turkey. In Economic Research 
Forum Working Papers (No. 0714).

13 Malysia, 2009-2011 Turkey

Total assets and Total deposits and equities

period income/loss

Loans Deposits, Number of investments employees

15 Greece

19931998

16 Chinese

2003-2011

17 Turkey

2012

2014

and Total Total Expenses
Labor, Physical capital, deposits or bad loans

Non-interest income(fees, commissions, capital,Labor,Number of full-time employees hired
Loan, Investment, Liquid Assets and

.

ADA, A. A., \& DALKILIÇ, N. (2014). Efficiency Analysis in Islamic Banks: A Study for Malaysia and Turkey. Journal of Brsa Banking \& Financial Markets, 8(1).

Karimzadeh, M. (2012). Efficiency analysis by using Data Envelop Analysis model: evidence from Indian banks. International Journal of Latest Trends in Finance and Economic Sciences, 2(3), 228-237.

Tsionas, E. G., Lolos, S. E., \&Christopoulos, D. K. (2003). The performance of the Greek banking system in view of the EMU: results from a non-parametric approach. Economic modelling, 20(3), 571-592.

Wang, K., Huang, W., Wu, J., \& Liu, Y. N. (2014). Efficiency measures of the Chinese commercial banking system using an additive two-stage DEA. Omega, 44, 5-20.

other busines income), Interest incomes, Nonperforming loans

Total Expense for Goals and Services" and "Surplus Income"

Özbek, A. (2015). Efficiency analysis of the Turkish red crescent between 2012 and 2014. International Journal of Economics and Finance, 7(9), 322334.

18 USA 1997-2007 Labor; (ii) Fixed assets; (iii) Deposits; and (iv) Non-interest expenses

Loans (total loans and leases, net of unearned income), (ii) securities (iii) off-balance sheet activities total noninterest income

Elyasiani, E., \& Wang, Y. (2012). Bank holding company diversification and production efficiency. Applied Financial Economics, 22(17), 1409-1428.

19 Bahrain 2000-2004

Fixed assets, Deposits, Short term funding, Equity, Personnel expenses

20 Australia 1995 to 1999 Labor and Physical capital

Deposits Loans

Loans, Other earning assets
Ramanathan, R. (2007). Performance of banks in countries of the Gulf Cooperation Council. International journal of productivity and performance management, 56(2), 137-154.

and Neal, P. (2004). X-efficiency and productivity change in Australian banking. Australian Economic Papers, 43(2), 174-191. 


\section{Determinants of financial Performance of Modaraba Companies}

\begin{tabular}{|c|c|c|c|c|c|}
\hline $\begin{array}{l}\text { First } \\
\text { Author } \\
\text { Name }\end{array}$ & $\begin{array}{l}\text { Year } \\
\text { Of } \\
\text { Public } \\
\text { ation }\end{array}$ & $\begin{array}{l}\text { Dependent } \\
\text { Variable }\end{array}$ & $\begin{array}{l}\text { Independent } \\
\text { Variable } \\
\text { (Firm Specific } \\
\text { \& Macro } \\
\text { Economic) } \\
\end{array}$ & Regression Method & Reference (APA style) \\
\hline $\begin{array}{l}\text { Wasim } \\
\text { ul } \\
\text { Rehma } \\
\text { n. }\end{array}$ & 2011 & $\begin{array}{l}\text { E.P.S., } \\
\text { ROE,ROI, }\end{array}$ & $\begin{array}{l}\text { Financial } \\
\text { Performance. }\end{array}$ & $\begin{array}{l}\text { VAIC .Value Added } \\
\text { Intellactual Coefficients. }\end{array}$ & $\begin{array}{l}\text { Rahman,w.u.chaudhary,AR.Rahma } \\
\mathrm{n} \text { H.u.,zahid A.(2011)Intellectual } \\
\text { capital performance and it's impact } \\
\text { on corporate performance:An } \\
\text { empirical evidence from } \\
\text { MODARBA sector of } \\
\text { PakistaN,Australian Journal of } \\
\text { Business and management } \\
\text { research,1(5),8. }\end{array}$ \\
\hline $\begin{array}{l}\text { Saher } \\
\text { Aqel }\end{array}$ & 2014 & $\begin{array}{l}\text { Di. } \\
\text { ROA. }\end{array}$ & $\begin{array}{l}\text { Firm Size } \\
\text {.Leverage. } \\
\text { Profitability. } \\
\text { Liquidity. }\end{array}$ & $\begin{array}{l}\text { Multicollinearity } \\
\text { Analysis } \quad . \text { Regression } \\
\text { Analysis. }\end{array}$ & $\begin{array}{l}\text { Abel,S.(2014).The determinants of } \\
\text { financial reporting on the } \\
\text { internet:the case of companies listed } \\
\text { in the Istanbul stock exchange. }\end{array}$ \\
\hline $\begin{array}{l}\text { Easily } \\
\text { Rehma } \\
\text { n. }\end{array}$ & 2011 & E.P.S.,ROE,ROI, & $\begin{array}{l}\text { Financial } \\
\text { Performance. }\end{array}$ & $\begin{array}{l}\text { VAIC .Value Added } \\
\text { Intellactual Coefficients. }\end{array}$ & $\begin{array}{l}\text { Rahman,w.u.chaudhary,AR.Rahma } \\
\mathrm{n} \text { H.u.,Zahid A.(2011)Intellectual } \\
\text { capital performance and it's impact } \\
\text { on corporate performance:An } \\
\text { empirical evidence from } \\
\text { MODARBA sector of } \\
\text { PakistaN,Australian Journal of } \\
\text { Business and management } \\
\text { research,1(5),8. }\end{array}$ \\
\hline $\begin{array}{l}\text { Talat } \\
\text { Afza. }\end{array}$ & 2014 & $\begin{array}{l}\text { T.C,ROE,ROR,F } \\
\text {.C,O.C,. }\end{array}$ & $\begin{array}{l}\text { Profit } \\
\text { Efficiency, } \\
\text { Technical } \\
\text { Efficiency, } \\
\text { Cost } \\
\text { Efficiency, }\end{array}$ & $\begin{array}{l}\text { EMPERICAL } \\
\text { STUDY,FA,FDH,DEA, } \\
\text { DHA. }\end{array}$ & $\begin{array}{l}\text { Gaza,R,Asghar,M.J.E.K.A.(2014)Ef } \\
\text { ficiency of modarba and leasing } \\
\text { companies in } \\
\text { Pakistan.procedia,social and } \\
\text { behavioral sciences, } 109,470-482 .\end{array}$ \\
\hline $\begin{array}{l}\text { Wasim } \\
\text { ul } \\
\text { Rehma } \\
\text { n. }\end{array}$ & 2011 & E.P.S.,ROE,ROI, & $\begin{array}{l}\text { Financial } \\
\text { Performance. }\end{array}$ & $\begin{array}{l}\text { VAIC .Value Added } \\
\text { Intellactual Coefficients. }\end{array}$ & $\begin{array}{l}\text { Rahman,w.u.chaudhary,AR.Rahma } \\
\mathrm{n} \text { H.u.,zahid A.(2011)Intellectual } \\
\text { capital performance and it's impact } \\
\text { on corporate performance:An } \\
\text { empirical evidence from } \\
\text { MODARBA sector of } \\
\text { PakistaN,Australian Journal of } \\
\text { Business and management } \\
\text { research,1(5),8. }\end{array}$ \\
\hline $\begin{array}{l}\text { Sara } \\
\text { Zafar, } \\
\text { Aliza } \\
\text { Nor }\end{array}$ & 2019 & $\begin{array}{l}\text { ROI, Agency } \\
\text { Cost, Risk }\end{array}$ & $\begin{array}{l}\text { Monitoring } \\
\text { Cost, Taxation, } \\
\text { Firm's Size, } \\
\text { Firm's Age, } \\
\text { Financial } \\
\text { Leverage }\end{array}$ & $\begin{array}{l}\text { Basic Model, Extended } \\
\text { Model }\end{array}$ & $\begin{array}{l}\text { Zafar, S., \& Nor, E. }(2019) \text {. } \\
\text { DETERMINANTS OF ROI IN } \\
\text { MUDARABAH } \\
\text { MUSHARAKAH CONTRACTS } \\
\text { IN PAKISTAN: } \\
\text { APPRAISAL. International Journal } \\
\text { of Business and Society, 20(3), } \\
\text { 1112-1129. }\end{array}$ \\
\hline $\begin{array}{l}\text { Muham } \\
\text { mad } \\
\text { Azam }\end{array}$ & 2019 & FP, EAT & $\begin{array}{l}\text { CSR, DIV( } \\
\text { Dividend } \\
\text { Distributon) }\end{array}$ & $\begin{array}{l}\text { Epistemological Model } \\
\text { Of The Unity }\end{array}$ & $\begin{array}{l}\text { Azam, M., Akhtar, J., Ali, S. A., \& } \\
\text { Mohy-Ud-Din, K. (2019). The } \\
\text { moderating role of Shariah } \\
\text { compliance on the relationship } \\
\text { between firm profitability and CSR } \\
\text { activities. International Journal of } \\
\text { Ethics and Systems. }\end{array}$ \\
\hline $\begin{array}{l}\text { Sara } \\
\text { Zafar, } \\
\text { Aliza }\end{array}$ & 2019 & $\begin{array}{l}\text { ROI, Agency } \\
\text { Cost, Risk }\end{array}$ & $\begin{array}{l}\text { Monitoring } \\
\text { Cost, Taxation, } \\
\text { Firm's Size, }\end{array}$ & $\begin{array}{l}\text { Basic Model, Extended } \\
\text { Model }\end{array}$ & $\begin{array}{l}\text { Zafar, S., \& Nor, E. } \\
\text { DETERMINANTS OF ROI IN } \\
\text { MUDARABAH }\end{array}$ \\
\hline
\end{tabular}




\begin{tabular}{|c|c|c|c|c|c|}
\hline Nor & & & $\begin{array}{l}\text { Firm's Age, } \\
\text { Financial } \\
\text { Leverage }\end{array}$ & & $\begin{array}{l}\text { MUSHARAKAH CONTRACTS } \\
\text { IN PAKISTAN: AN } \\
\text { APPRAISAL. International Journal } \\
\text { of Business and Society, 20(3), } \\
1112-1129 \text {. }\end{array}$ \\
\hline $\begin{array}{l}\text { Muham } \\
\text { mad } \\
\text { Azam }\end{array}$ & 2019 & FP, EAT & $\begin{array}{l}\text { CSR, DIV( } \\
\text { Dividend } \\
\text { Distribution) }\end{array}$ & $\begin{array}{l}\text { Epistemological Model } \\
\text { Of The Unity }\end{array}$ & $\begin{array}{l}\text { Azam, M., Akhtar, J., Ali, S. A., \& } \\
\text { Mohy-Ud-Din, K. (2019). The } \\
\text { moderating role of Shariah } \\
\text { compliance on the relationship } \\
\text { between firm profitability and CSR } \\
\text { activities. International Journal of } \\
\text { Ethics and Systems. }\end{array}$ \\
\hline $\begin{array}{l}\text { Sara } \\
\text { Zafar, } \\
\text { Aliza } \\
\text { Nor }\end{array}$ & 2019 & $\begin{array}{l}\text { ROI, Agency } \\
\text { Cost, Risk }\end{array}$ & $\begin{array}{l}\text { Monitoring } \\
\text { Cost, Taxation, } \\
\text { Firm's Size, } \\
\text { Firm's Age, } \\
\text { Financial } \\
\text { Leverage }\end{array}$ & $\begin{array}{l}\text { Basic Model, Extended } \\
\text { Model }\end{array}$ & $\begin{array}{l}\text { Zafar, S., \& Nor, E. (2019). } \\
\text { DETERMINANTS OF ROI IN } \\
\text { MUDARABAH } \\
\text { MUSHARAKAH CONTRACTS } \\
\text { IN PAKISTAN: } \\
\text { APPRAISAL. International Journal } \\
\text { of Business and Society, 20(3), } \\
\text { 1112-1129. }\end{array}$ \\
\hline $\begin{array}{l}\text { Muham } \\
\text { mad } \\
\text { Azam }\end{array}$ & 2019 & FP, EAT & $\begin{array}{l}\text { CSR, DIV( } \\
\text { Dividend } \\
\text { distribution) }\end{array}$ & $\begin{array}{l}\text { Epistemological Model } \\
\text { Of The Unity }\end{array}$ & $\begin{array}{l}\text { Azam, M., Akhtar, J., Ali, S. A., \& } \\
\text { Mohy-Ud-Din, K. (2019). The } \\
\text { moderating role of Shariah } \\
\text { compliance on the relationship } \\
\text { between firm profitability and CSR } \\
\text { activities. International Journal of } \\
\text { Ethics and Systems. }\end{array}$ \\
\hline $\begin{array}{l}\text { Sara } \\
\text { Zafar, } \\
\text { Aliza } \\
\text { Nor }\end{array}$ & 2019 & $\begin{array}{l}\text { ROI, Agency } \\
\text { Cost, Risk }\end{array}$ & $\begin{array}{l}\text { Monitoring } \\
\text { Cost, Taxation, } \\
\text { Firm's Size, } \\
\text { Firm's Age, } \\
\text { Financial } \\
\text { Leverage }\end{array}$ & $\begin{array}{l}\text { Basic Model, Extended } \\
\text { Model }\end{array}$ & $\begin{array}{l}\text { Zafar, S., \& } \\
\text { DETERMINANTS OF E. (2019). } \\
\text { MUDARABAH }\end{array}$ \\
\hline $\begin{array}{l}\text { Muham } \\
\text { mad } \\
\text { Azam }\end{array}$ & 2019 & FP, EAT & $\begin{array}{l}\text { CSR, DIV( } \\
\text { Dividend } \\
\text { distribution) }\end{array}$ & $\begin{array}{l}\text { Epistemological Model } \\
\text { Of The Unity }\end{array}$ & $\begin{array}{l}\text { Azam, M., Akhtar, J., Ali, S. A., \& } \\
\text { Mohy-Ud-Din, K. (2019). The } \\
\text { moderating role of Shariah } \\
\text { compliance on the relationship } \\
\text { between firm profitability and CSR } \\
\text { activities. International Journal of } \\
\text { Ethics and Systems. }\end{array}$ \\
\hline $\begin{array}{l}\text { Talat } \\
\text { Afza. }\end{array}$ & 2014 & $\begin{array}{l}\text { T.C,ROE,ROR,F } \\
\text {.C,O.C,. }\end{array}$ & $\begin{array}{l}\text { Profit } \\
\text { Efficiency, } \\
\text { Technical } \\
\text { Efficiency, } \\
\text { Cost } \\
\text { Efficiency, }\end{array}$ & $\begin{array}{l}\text { EMPERICAL } \\
\text { STUDY,FA,FDH,DEA, } \\
\text { DHA. }\end{array}$ & $\begin{array}{l}\text { Gaza,R,Asghar,M.J.E.K.A.(2014)Ef } \\
\text { ficiency of modarba and leasing } \\
\text { companies in } \\
\text { Pakistan.procedia,social and } \\
\text { behavioral sciences,109,470-482. }\end{array}$ \\
\hline $\begin{array}{l}\text { Wasim } \\
\text { ul } \\
\text { Rehma } \\
\text { n. }\end{array}$ & 2011 & E.P.S.,ROE,ROI, & $\begin{array}{l}\text { Financial } \\
\text { Performance. }\end{array}$ & $\begin{array}{l}\text { VAIC .Value Added } \\
\text { Intellectual Coefficients. }\end{array}$ & $\begin{array}{l}\text { Rahman,w.u.chaudhary,AR.Rahma } \\
\mathrm{n} \text { H.u.,zahid A.(2011)Intellectual } \\
\text { capital performance and its impact } \\
\text { on corporate performance: An } \\
\text { empirical evidence from } \\
\text { MODARBA sector of Pakistan, } \\
\text { Australian Journal of Business and } \\
\text { management research,1(5),8. }\end{array}$ \\
\hline $\begin{array}{l}\text { Irfan } \\
\text { Ullah, } \\
\text { Wiqar } \\
\text { Ahmad } \\
\text { And } \\
\text { Arshad }\end{array}$ & & $\begin{array}{l}\text { ROA } \\
\text { Investment } \\
\text { Decisions. }\end{array}$ & $\begin{array}{l}\text { The Monetary } \\
\text { Stimulus, The } \\
\text { Religiosity } \\
\text { Stimulus And } \\
\text { The Lubricants }\end{array}$ & 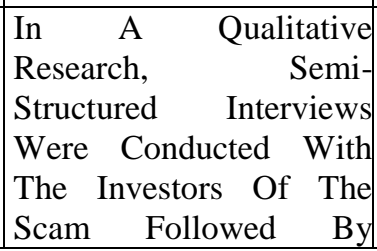 & $\begin{array}{l}\text { Ullah, I., Ahmad, W., \& Ali, A. } \\
\text { (2020). Determinants of investment } \\
\text { decision in a Ponzi scheme: } \\
\text { Investors perspective on the } \\
\text { Modaraba scam. Journal of } \\
\text { Financial Crime. }\end{array}$ \\
\hline
\end{tabular}




\begin{tabular}{|c|c|c|c|c|c|}
\hline Ali & & & & $\begin{array}{|lcr|}\text { Thematic } & \text { Analysis } & \text { To } \\
\text { Conclude } & \text { On } & \text { The } \\
\text { Subject Matter. } & \\
\end{array}$ & \\
\hline $\begin{array}{l}\text { Sara } \\
\text { Zafar, } \\
\text { Eliza } \\
\text { Nor }\end{array}$ & 2019 & $\begin{array}{l}\text { ROI, AGENCY } \\
\text { COST, RISK }\end{array}$ & $\begin{array}{lr}\text { Firm's Age, } \\
\text { Size And } \\
\text { Financial } \\
\text { Leverage }\end{array}$ & $\begin{array}{l}\text { Data Will Be } \text { Collected } \\
\text { From The Annual } \\
\text { Reports Of Mudarabah } \\
\text { Companies Listed In The } \\
\text { Pakistan Stock Exchange } \\
\text { (PSX). }\end{array}$ & $\begin{array}{l}\text { Zafar, S., \& Nor, E. (2019). } \\
\text { DETERMINANTS OF ROI IN } \\
\text { MUDARABAH } \\
\text { MUSHARAKAH CONTRACTS } \\
\text { IN PAKISTAN: } \\
\text { APPRAISAL. International Journal } \\
\text { of Business and Society, 20(3), } \\
1112-1129 .\end{array}$ \\
\hline $\begin{array}{l}\text { Sara } \\
\text { Zafar }\end{array}$ & 2019 & ROI & $\begin{array}{l}\text { Agency Cost, } \\
\text { Monitoring } \\
\text { Cost,Taxation, } \\
\text { Firm Size. } \\
\text { Firm Age, Risk }\end{array}$ & Regression Model & $\begin{array}{l}\text { Zafar, S., \& Nor, E. (2019). } \\
\text { DETERMINANTS OF ROI IN } \\
\text { MUDARABAH } \\
\text { MUSHARAKAH CONTRACTS } \\
\text { IN PAKISTAN: } \\
\text { APPRAISAL. International Journal } \\
\text { of Business and Society, 20(3), } \\
1112-1129 .\end{array}$ \\
\hline $\begin{array}{l}\text { Sara } \\
\text { Zafar }\end{array}$ & 2019 & ROI & $\begin{array}{l}\text { Agency Cost, } \\
\text { Monitoring } \\
\text { Cost,Taxation, } \\
\text { Firm Size. } \\
\text { Firm Age, Risk }\end{array}$ & Regression Model & $\begin{array}{l}\text { Zafar, S., \& Nor, E. (2019). } \\
\text { DETERMINANTS OF ROI IN } \\
\text { MUDARABAH } \\
\text { MUSHARAKAH CONTRACTS } \\
\text { IN PAKISTAN: } \\
\text { APPRAISAL. International Journal } \\
\text { of Business and Society, 20(3), } \\
\text { 1112-1129. }\end{array}$ \\
\hline $\begin{array}{l}\text { Sara } \\
\text { Zafar }\end{array}$ & 2019 & ROI & $\begin{array}{l}\text { Agency Cost, } \\
\text { Monitoring } \\
\text { Cost,Taxation, } \\
\text { Firm Size. } \\
\text { Firm Age, Risk }\end{array}$ & Regression Model & $\begin{array}{l}\text { Zafar, S., \& Nor, E. (2019). } \\
\text { DETERMINANTS OF ROI IN } \\
\text { MUDARABAH } \\
\text { MUSHARAKAH CONTRACTS } \\
\text { IN PAKISTAN: } \\
\text { APPRAISAL. International Journal } \\
\text { of Business and Society, 20(3), } \\
1112-1129 .\end{array}$ \\
\hline $\begin{array}{l}\text { Satwind } \\
\text { er } \\
\text { Singh }\end{array}$ & 2017 & TQ,ROA,ROE & $\begin{array}{l}\text { Board Size, } \\
\text { Board } \\
\text { Independence } \\
\text {,Age, Size, } \\
\text { Leverage }\end{array}$ & Estimation Method & $\begin{array}{l}\text { Singh, S., Tabassum, N., Darwish, } \\
\text { T. K., \& Batsakis, G. (2018). } \\
\text { Corporate governance and Tobin's } \\
\text { Q as a measure of organizational } \\
\text { performance. British Journal of } \\
\text { Management, 29(1), 171-190. }\end{array}$ \\
\hline $\begin{array}{l}\text { Muham } \\
\text { mad } \\
\text { Jam-E- } \\
\text { Kausar } \\
\text { Ali } \\
\text { Asghar }\end{array}$ & 2013 & $\begin{array}{lr}\text { Labour } & \& \\
\text { Business } & \\
\text { Services } & \\
\text { investment } \quad \text { In } \\
\text { Lease Finance } \\
\text { lease } \quad \& \\
\text { Investment } \\
\text { Income: }\end{array}$ & $\begin{array}{l}\text { Total Profit } \\
\text { total Cost: } \\
\text { Price Of Debt: } \\
\text { Debt: Price Of } \\
\text { L \& Labour \& } \\
\text { Business } \\
\text { Services } \\
\text { investment } \\
\text { total Income }\end{array}$ & $\begin{array}{lr}\text { Parametric } & \text { Stochastic } \\
\text { Frontier Approach (SFA }\end{array}$ & $\begin{array}{l}\text { Afza, T., \& Asghar, M. J. E. K. A. } \\
\text { (2014). Efficiency of modaraba and } \\
\text { leasing companies in } \\
\text { Pakistan. Procedia-Social and } \\
\text { Behavioral Sciences, } 109,470-482 .\end{array}$ \\
\hline $\begin{array}{l}\text { Talat } \\
\text { Afza }\end{array}$ & 2014 & $\begin{array}{l}\text { Total Income } \\
\text { From } \\
\text { Sharia } \\
\text { Compliance. } \\
\text { Investments And } \\
\text { Lease } \\
\text { Finance Income } \\
\end{array}$ & & $\begin{array}{l}\text { Stochastic Frontier } \\
\text { Approach (SFA). }\end{array}$ & $\begin{array}{l}\text { Afza, T., \& Asghar, M. J. E. K. A. } \\
\text { (2014). Efficiency of modaraba and } \\
\text { leasing companies in } \\
\text { Pakistan. Procedia-Social and } \\
\text { Behavioral Sciences, } 109,470-482 .\end{array}$ \\
\hline $\begin{array}{l}\text { Muham } \\
\text { mad } \\
\text { Jam-E- } \\
\text { Kausar } \\
\text { Ali }\end{array}$ & 2013 & $\begin{array}{lr}\text { Labour } & \& \\
\text { Business } & \\
\text { Services } & \\
\text { investment } \quad \text { In } \\
\text { Lease } \quad \text { Finance }\end{array}$ & 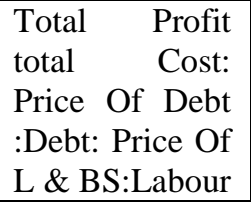 & $\begin{array}{l}\text { Parametric Stochastic } \\
\text { Frontier Approach (SFA }\end{array}$ & $\begin{array}{l}\text { Afza, T., \& Asghar, M. J. E. K. A. A. } \\
\text { (2014). Efficiency of modaraba and } \\
\text { leasing companies in } \\
\text { Pakistan. Procedia-Social and } \\
\text { Behavioral Sciences, } 109,470-482 .\end{array}$ \\
\hline
\end{tabular}




\begin{tabular}{|c|c|c|c|c|c|}
\hline Asghar & & $\begin{array}{l}\text { lease } \quad \& \\
\text { Investment } \\
\text { Income: }\end{array}$ & $\begin{array}{l}\text { \& Business } \\
\text { Services } \\
\text { investment } \\
\text { total Income }\end{array}$ & & \\
\hline $\begin{array}{l}\text { Talat } \\
\text { Afzaa }\end{array}$ & 2014 & $\begin{array}{l}\text { Total Income } \\
\text { From } \\
\text { Sharia } \\
\text { Compliance. } \\
\text { Investments And } \\
\text { Lease } \\
\text { Finance Income }\end{array}$ & & $\begin{array}{l}\text { Stochastic Frontier } \\
\text { Approach (SFA). }\end{array}$ & $\begin{array}{l}\text { Afza, T., \& Asghar, M. J. E. K. A. } \\
\text { (2014). Efficiency of modaraba and } \\
\text { leasing companies and } \\
\text { Pakistan. Procedia-Social in } \\
\text { Behavioral Sciences, 109, 470-482. }\end{array}$ \\
\hline $\begin{array}{l}\text { Muham } \\
\text { mad } \\
\text { Jam-E- } \\
\text { Kausar } \\
\text { Ali } \\
\text { Asghar }\end{array}$ & 2013 & $\begin{array}{l}\text { Economic Value } \\
\text { Added } \\
\text { (Financial } \\
\text { Performance) }\end{array}$ & $\begin{array}{l}\text { Total Profit } \\
\text { total Cost: Price } \\
\text { of Debt: Debt: } \\
\text { Price of L \& } \\
\text { BS:Labour \& } \\
\text { Business } \\
\text { Services } \\
\text { investment total } \\
\text { Income }\end{array}$ & $\begin{array}{l}\text { Parametric Stochastic } \\
\text { Frontier Approach (SFA }\end{array}$ & $\begin{array}{l}\text { Afza, T., \& Asghar, M. J. E. K. A. } \\
\text { (2014). Efficiency of modaraba and } \\
\text { leasing companies in } \\
\text { Pakistan. Procedia-Social and } \\
\text { Behavioral Sciences, 109, 470-482. }\end{array}$ \\
\hline $\begin{array}{l}\text { Talat } \\
\text { Afzaa }\end{array}$ & 2014 & EVA & $\begin{array}{l}\text { Leverage, } \\
\text { Liquidity, Size, } \\
\text { Risk, And } \\
\text { Tangibility }\end{array}$ & $\begin{array}{l}\text { Stochastic Frontier } \\
\text { Approach (SFA). }\end{array}$ & $\begin{array}{l}\text { Afza, T., \& Asghar, M. J. E. K. A. } \\
\text { (2014). Efficiency of modaraba and } \\
\text { leasing companies in } \\
\text { Pakistan. Procedia-Social and } \\
\text { Behavioral Sciences, } 109,470-482 \text {. }\end{array}$ \\
\hline $\begin{array}{l}\text { MA } \\
\text { Siddiqu } \\
\text { e }\end{array}$ & 2020 & ROI,ROA & $\begin{array}{l}\text { Interest Rate, } \\
\text { GDP, Number } \\
\text { Of Employee }\end{array}$ & $\begin{array}{l}\text { Uses Salam, Murabaha, } \\
\text { Diminishing Musharakah } \\
\text { (DM), Ijarah, And Istisna } \\
\text { As Dependent Variables. } \\
\text { Four Fully Fledged And } \\
\text { Five } \\
\text { Branches } \\
\text { Conventional Standalone } \\
\text { Were } \\
\text { Unbalanced Panel Data } \\
\text { For 2004 To 2017 } \\
\end{array}$ & $\begin{array}{l}\text { Siddique, M.A., Haq, M. and } \\
\text { Rahim, M., 2020. The Impact of the } \\
\text { Islamic Banking Industry on } \\
\text { Economic Growth and Poverty } \\
\text { Reduction in Pakistan. In Enhancing } \\
\text { Financial Inclusion through Islamic } \\
\text { Finance, Volume II (pp. 259-279). } \\
\text { Palgrave Macmillan, Cham. }\end{array}$ \\
\hline $\begin{array}{l}\text { WH } \\
\text { Ahmad } \\
\text { AA } \\
\text { ALI }\end{array}$ & 2020 & ROA & $\begin{array}{l}\text { Interest Rate, } \\
\text { GDP, Number } \\
\text { Of Employee }\end{array}$ & $\begin{array}{lr}\text { In A } & \text { Qualitative } \\
\text { Research, } & \text { Semi- } \\
\text { Structured Interviews } \\
\text { Were Conducted With } \\
\text { The Investors Of } & \text { The } \\
\text { Scam Followed } & \text { By } \\
\text { Thematic Analysis } & \text { To } \\
\text { Conclude On } & \text { The } \\
\text { Subject Matter } & \\
\end{array}$ & $\begin{array}{l}\text { Ullah, I., Ahmad, W. and Ali, A., } \\
\text { 2020. Determinants of investment } \\
\text { decision in a Ponzi scheme: } \\
\text { Investors' perspective on the } \\
\text { Modaraba scam. Journal of } \\
\text { Financial Crime. }\end{array}$ \\
\hline $\begin{array}{l}\text { Islam,A } \\
\text { hmad }\end{array}$ & 2019 & $\begin{array}{l}\text { Profit And Loss } \\
\text { Sharing, Islamic } \\
\text { Microfinance, } \\
\text { Poverty } \\
\text { Alleviation }\end{array}$ & $\begin{array}{l}\text { Identification, } \\
\text { Measurement, } \\
\text { Monitoring,Co } \\
\text { ntrolling,Religi } \\
\text { osity,Knowled } \\
\text { ge,Entrepreneu } \\
\text { rship }\end{array}$ & $\begin{array}{l}\text { Chi Square, } \\
\text { RMSEA,NFI,TLI }\end{array}$ & $\begin{array}{l}\text { Islam, R., \& Ahmad, R. (2020). } \\
\text { Applicability of Mudarabah and } \\
\text { Musharakah as Islamic Micro- } \\
\text { equity Finance to Underprivileged } \\
\text { Women in Malaysia. The European } \\
\text { Journal of Development Research, } \\
\text { 32(1), 176-197. }\end{array}$ \\
\hline $\begin{array}{l}\text { Islam,A } \\
\text { hmad }\end{array}$ & 2019 & $\begin{array}{l}\text { Profit And Loss } \\
\text { Sharing, Islamic } \\
\text { Microfinance, } \\
\text { Poverty } \\
\text { Alleviation }\end{array}$ & $\begin{array}{l}\text { Identification, } \\
\text { Measurement, } \\
\text { Monitoring,Co } \\
\text { ntrolling,Religi } \\
\text { osity,Knowled } \\
\text { ge,Entrepreneu } \\
\text { rship }\end{array}$ & $\begin{array}{l}\text { Chi Square, } \\
\text { RMSEA,NFI,TLI }\end{array}$ & $\begin{array}{l}\text { Islam, R., \& Ahmad, R. (2020). } \\
\text { Applicability of Mudarabah and } \\
\text { Musharakah as Islamic Micro- } \\
\text { equity Finance to Underprivileged } \\
\text { Women in Malaysia. The European } \\
\text { Journal of Development Research, } \\
\text { 32(1), 176-197. }\end{array}$ \\
\hline $\begin{array}{l}\text { MA } \\
\text { Siddiqu } \\
\text { e }\end{array}$ & 2020 & ROI,ROA & $\begin{array}{l}\text { Interest Rate, } \\
\text { GDP, Number } \\
\text { Of Employee }\end{array}$ & $\begin{array}{lr}\text { The Study } & \text { Uses } \\
\text { Murabaha, Salam, } \\
\text { Musharakah } & \text { Diminishing } \\
\end{array}$ & $\begin{array}{l}\text { Siddique, M.A., Haq, M. and } \\
\text { Rahim, M., 2020. The Impact of the } \\
\text { Islamic Banking Industry on }\end{array}$ \\
\hline
\end{tabular}




\begin{tabular}{|c|c|c|c|c|c|}
\hline & & & & \begin{tabular}{lrr|} 
Ijarah, And & Istisna & As \\
Dependent & Variables. \\
Conventional & Banks \\
Were r Selected. & It \\
Employs & Annual \\
Unbalanced & Panel & Data \\
For 2004 To & 2017 &
\end{tabular} & $\begin{array}{l}\text { Economic Growth and Poverty } \\
\text { Reduction in Pakistan. In Enhancing } \\
\text { Financial Inclusion through Islamic } \\
\text { Finance, Volume II (pp. 259-279). } \\
\text { Palgrave Macmillan, Cham. }\end{array}$ \\
\hline $\begin{array}{l}\text { WH } \\
\text { Ahmad } \\
\text { AA } \\
\text { ALI }\end{array}$ & 2020 & ROA & $\begin{array}{l}\text { Interest Rate, } \\
\text { GDP, Number } \\
\text { Of Employee }\end{array}$ & $\begin{array}{l}\text { Semi-Structured Inter- } \\
\text { views Were Conducted } \\
\text { With The Investors of } \\
\text { The Scam Followed By } \\
\text { Thematic Analysis }\end{array}$ & $\begin{array}{l}\text { Ullah, I., Ahmad, W. and Ali, A., } \\
\text { 2020. Determinants of investment } \\
\text { decision in a Ponzi scheme: } \\
\text { Investors perspective on the } \\
\text { Modaraba scam. Journal of Financial } \\
\text { Crime. }\end{array}$ \\
\hline
\end{tabular}

